Invest. Pens. Crit. (ISSN 1812-3864; eISSN 2644-4119)

DOI: https://doi.org/10.37387/ipc.v8i2.148

Vol. 8, No. 2, Mayo - Agosto 2020

pp. $93-98$

\title{
Escenario internacional y desafíos a la democracia en Panamá
}

\author{
Dr. Carlos Guevara Mann ${ }^{1, *}$ \\ ${ }^{1}$ Profesor de Ciencias Políticas y Director de la Maestría en \\ Relaciones Internacionales de Florida State University, Panamá \\ *Autor para correspondencia: cguevara@,fsu.edu
}

Recibido: 11 de febrero de 2020

Aceptado: 05 de marzo de 2020

Tres décadas atrás, a inicios de 1990, nuestro país daba los primeros pasos hacia la normalización política y económica. Se trataba reorganizar el desenvolvimiento de la vida nacional dentro del marco jurídico de la constitución de 1972, reiteradamente pisoteada por sus propios creadores.

La reconstrucción nacional que se intentaba en los primeros meses de 1990 era titánica. El país acababa de ser blanco de una acción armada extranjera, que estuvo acompañada por un vergonzoso saqueo.

Esa invasión fue el punto culminante de la aguda crisis política y económica que aquejó a la nación panameña en los dos años precedentes, la cual no pudo resolverse mediante la vía electoral, porque los militares en el poder y sus socios civiles desconocieron los resultados de la elección presidencial del 7 de mayo de 1989. Deseaban continuar al mando del país, como lo habían hecho durante 21 años, al frente de una dictadura que desarticuló las fundaciones republicanas y democráticas del Estado panameño; supeditó el Estado de derecho a los apetitos del tirano de turno; estranguló las libertades individuales; exacerbó la demagogia seudo nacionalista, la represión y el populismo para mantener su vigencia; e hizo lo posible por erradicar el civismo de la esfera pública, transformado a los panameños, de ciudadanos que éramos a la víspera del golpe militar, en suplicantes vasallos del déspota en el poder.

Es importante que los panameños tengamos presentes estos hechos, en primera instancia, para que justipreciemos los logros alcanzados en los treinta años transcurridos tras el desalojo de la dictadura y, en segundo lugar, para reafirmar nuestro compromiso hacia una auténtica, sólida y duradera democracia.

Al hacerse cargo del poder, el presidente Guillermo Endara, elegido por una abrumadora mayoría de votantes en mayo de 1989, asumió la difícil tarea de reconducir al país por la senda del constitucionalismo y la democracia. Las condiciones internas, como hemos visto, no eran las más propicias para la democratización. Pero de afuera sí soplaban vientos favorables a la democracia. 
E19 de noviembre de 1989, el derrumbe del muro de Berlín simbolizó, de la forma más gráfica posible, el final del imperio soviético en Europa oriental y la liberación, del yugo moscovita, de seis países: Alemania Oriental, Bulgaria, Checoslovaquia, Hungría, Polonia y Rumanía, extendiéndose con ello la tercera ola de la democracia detrás de la cortina de hierro.

Esta tercera ola de la democracia, como lo planteó el profesor Huntington, ${ }^{1}$ ya abarcaba a América Latina desde finales de la década del setenta. En 1986-1988, la prestigiosa ONG internacional Freedom House clasificaba como Estados "libres" a once repúblicas en una región donde, una década antes, solo había tres democracias liberales. ${ }^{2}$ A pesar del trauma que significó la remoción de la dictadura militar panameña, el panorama mundial y el contexto regional daban a los demócratas del istmo esperanzas de que nuestro país pudiese avanzar por el camino que siguieron los Estados de Europa Oriental y algunos de América Latina.

Panamá, efectivamente, transitó a una democracia formal durante la presidencia de Guillermo Endara (1989-1994). Desde que, según Freedom House, alcanzamos la categoría de Estado "libre"—en 1994-hemos mantenido esa clasificación ininterrumpidamente. En efecto, formamos parte de un reducido grupo de países que, después de obtener dicha clasificación durante la tercera ola de la democracia, la ha conservado sin interrupciones. ${ }^{3}$

¿Qué ha significado, para Panamá, formar parte del grupo de países que califican como Estados "libres" de América Latina? En primera instancia: la normalización en el ejercicio del poder, conforme a la constitución de 1972. Esto quiere decir que cada cinco años tienen lugar elecciones populares competitivas, a partir de las cuales asumen el poder ejecutivo, el poder legislativo y los cargos municipales los candidatos a quienes se proclama elegidos. Estos individuos inician y terminan sus funciones según el calendario constitucional, sin amenazas de consideración, atentados inconstitucionales o golpes de Estado.

Esta normalización representa un importante salto cualitativo en comparación con la situación imperante desde la instauración del sistema republicano en nuestro medio, casi doscientos años atrás (en 1821) hasta el derrocamiento de la dictadura militar. Un aspecto de nuestra historia política republicana es, precisamente, la inestable rotación en la jefatura del ejecutivo, sobre todo durante el período federal de unión a Colombia (1855-1885), al igual que a mediados del siglo XX (1931-1968) y a lo largo de la dictadura militar (1968-1989), cuando tuvimos nueve presidentes "desechables" en 21 años, un promedio de uno cada dos años y cuatro meses. El tránsito a la democracia significó la superación de esta inestabilidad. Desde 1994, seis presidentes han iniciado y concluido sus períodos conforme a la constitución: toda una proeza, en el contexto histórico panameño y latinoamericano.

\footnotetext{
${ }^{1}$ Samuel P. Huntington, The Third Wave: Democratization in the Late Twentieth Century (Norman: University of Oklahoma Press, 1991).

2 Freedom House, "About Freedom in the World: Country and Territory Ratings and Statuses, 1973-2019 (Excel)," en https://freedomhouse.org/report-types/freedom-world. Acceso: 16 de febrero de 2020. En 1976-1977, solo Colombia, Costa Rica y Venezuela clasificaban como países "libres" o democracias liberales. En 1986-1988, Argentina, Bolivia, Brasil, Colombia, Costa Rica, El Salvador, Honduras, Perú, República Dominicana, Uruguay y Venezuela recibieron esa misma clasificación.

${ }^{3}$ Costa Rica (1949), Uruguay (1985), Chile (1990), Panamá (1994) y El Salvador (1997) (cinco Estados en total).
} 
Como resultado del desalojo de la dictadura obtuvimos, también, la alternancia en el ejercicio del poder y un mayor respeto por algunas libertades fundamentales. Liberadas de las ataduras a que las sometió la dictadura, garantías fundamentales como el derecho a la libre expresión, a la asociación con fines lícitos y a solicitar respuestas de los gobernantes, han logrado una mayor amplitud, aunque distan mucho de ejercerse efectivamente.

Un fenómeno característico de la post-dictadura en Panamá es el crecimiento económico. La economía panameña ha crecido cada año, desde 1990 en adelante. Aunque, evidentemente, la tasa de crecimiento no ha sido siempre igual y, en algunos momentos-sobre todo, a inicios del nuevo milenio-el ritmo del crecimiento se ha ralentizado significativamente, en ningún año se han reportado contracciones económicas. Esto diferencia al período democrático del período dictatorial, durante el cual el país experimentó contracciones económicas en 1983 (-4.5\%), 1987 (-1.8\%) y 1988 $(-13.8 \%) .{ }^{4}$ El crecimiento económico es un logro interesante, cuyas conexiones con el sistema político establecido treinta años atrás deben ser estudiadas con mayor cuidado a fin de determinar correlaciones y causalidades, como se ha hecho para otros países.

A pesar de la normalización en el ejercicio de los cargos de elección y de la ampliación del ámbito de la autonomía individual, Panamá no ha logrado avanzar significativamente hacia una mayor democratización de su vida política. Más allá de la concurrencia a las urnas, que se sitúa en aproximadamente $75 \%$ del electorado, ${ }^{5}$ la participación ciudadana en la toma de decisiones que afectan a la sociedad es limitada.

Esta participación encuentra grandes obstáculos. A los ciudadanos se nos dificulta tomar parte en un sistema político controlado por las cúpulas de los partidos, lo que contribuye a configurar un régimen bastante semejante a una partidocracia. Fuera de los partidos, la participación ciudadana es aún más difícil. Las peticiones, solicitudes, quejas y reclamos de la población no son genuinamente atendidos ni en la esfera municipal ni en el ámbito nacional porque, más allá de las votaciones a los cargos de elección popular - que ocurren simultáneamente, cada cinco años (un lapso demasiado prolongado)— no hay adecuados mecanismos de rendición de cuentas. Existen, claro está, las instituciones que, conforme al principio republicano, deben ejercer esa fiscalización y ese control, pero ni la Asamblea Nacional, ni el Órgano Judicial, ni el Ministerio Público, ni la Contraloría General de la República, ni la Defensoría del Pueblo, ni los gobiernos municipales cumplen con su cometido.

En la búsqueda de los factores detrás de esta ineficacia, debemos considerar, con mucho detenimiento, el inadecuado diseño constitucional, que proviene de la dictadura militar y debió ser descartado en 1990 por sus orígenes antidemocráticos, pero se mantuvo vigente. Panamá es un país que, como Chile, ha pretendido organizar su vida en democracia bajo una constitución emanada de los cuarteles. Como lo hemos visto recientemente en Chile, esa es una mescolanza incoherente.

\footnotetext{
${ }^{4}$ Centro Nacional de Competitividad (CNC), "Productividad total de factores: el caso de Panamá" (Panamá: CNC, s.f.), anexo I, https://cncpanama.org/phocadownload/Productividad\%20Total\%20de\%20Factores.\%20El\%20caso\%20de\%20Pana ma.pdf, acceso: 21 de marzo de 2020.

5 Isabel Díaz, "Participación en las elecciones de Panamá es alta en comparación a otros países de la región”, Panamá América, 7 de mayo de 2019, https://www.panamaamerica.com.pa/politica/participacion-en-las-eleccionesde-panama-es-alta-en-comparacion-otros-paises-de-la-region. Acceso: 16 de febrero de 2020.
} 
Uno de los peores aspectos de la constitución de 1972 es el sistema de representación política que instituye. En una democracia liberal, la participación ciudadana va de la mano del sistema de representación, que permite exponer las preocupaciones ciudadanas en los escenarios de toma de decisiones nacionales y locales (en Panamá, la Asamblea Nacional y los consejos municipales, respectivamente). La metodología instituida en la Constitución Política (y el Código Electoral) para la elección de diputados, sin embargo, favorece el personalismo y el clientelismo, contribuyendo de esa manera a la elección de un elemento poco idóneo para el desempeño de las importantes tareas de fiscalización y control de los otros órganos del Estado, que tampoco están debidamente estatuidas en dicha carta fundamental.

En cuanto al sistema municipal — uno de los pilares de la democracia liberal, según lo expuso nada menos que el Dr. Justo Arosemena, nuestro principal estadista-puede afirmarse, sin temor a equivocaciones, que la constitución de 1972 lo desbarató, imponiendo, en lugar de los concejales que antes constituían la cámara edilicia, a los llamados representantes de corregimiento, elegidos sobre bases de clientelismo y corrupción. Esos mal llamados "representantes" se constituyeron, en las palabras del jurisconsulto Humberto E. Ricord, en la "base populachera" de apoyo a la dictadura militar. ${ }^{6}$ A pesar de ello, han perdurado en el tiempo y el espacio. Hoy, sus principales preocupaciones no son la vigilancia permanente de la administración de sus distritos, sino el reparto de dádivas, canonjías y prebendas, con fines electoreros y de enriquecimiento personal.

De la mano de un sistema constitucional inapropiado, un sistema electoral inadecuado contribuye al mal funcionamiento de los órganos del Estado y a obstaculizar la participación ciudadana. Al igual que las raíces de la Constitución Política, los orígenes de ese sistema electoral se encuentran en las entrañas de la dictadura militar. En treinta años de democracia no ha sido democratizado ni depurado de sus rasgos más característicos, que son el clientelismo y la corrupción. Son esos, y no la libre voluntad ciudadana, los factores que explican el acceso a los cargos de representación popular en Panamá. En consecuencia, la compra de votos sigue siendo el método más eficaz para acceder a un puesto de elección y quienes así alcanzan los escaños de la representación política, no lo hacen motivados por promover el bien común, sino por resarcir sus gastos y obtener copiosas ganancias.

El sistema político de la democracia panameña, procedente de la dictadura militar, ya da señales de estrés. Si no se ataca la raíz del problema-una estructura constitucional y electoral que promueve el clientelismo, la corrupción y el divorcio entre cargos públicos y ciudadanos-corremos el riesgo de perder los logros de la democracia, que han caracterizado a Panamá en su etapa más reciente: el ejercicio del poder público sin interrupciones extra constitucionales, su puntual renovación conforme al calendario constitucional y un mayor espacio para la expresión individual y colectiva.

Necesitamos mantener y profundizar la democracia, no solo para conservar esos logros, sino, además, para proveer soluciones, mediante fórmulas pacíficas y de consenso, a importantes problemas nacionales: la inseguridad alimentaria y nutricional; la contaminación, la falta de saneamiento y la depredación ambiental; los reducidos niveles educativos de la población; los tremendos obstáculos en el acceso a la salud y la seguridad social; el bajo nivel de ingresos frente al ascendente costo de la vida; las enormes complicaciones e inseguridades en el transporte público; la creciente criminalidad; el inadecuado acceso a la justicia; y la falta de probidad en las actuaciones públicas, entre otros.

${ }^{6}$ Humberto E. Ricord, Noriega y Panamá: orgía y aplastamiento de la dictadura (México: edición del autor, 1991), pág. 74. 
Ante las voces que reclaman, cada vez con mayor insistencia, respuestas a todas estas situaciones y expresan frustración por la incapacidad del Estado de proveerlas, debemos recordar que no es el mesianismo populista, ni una dictadura militarista, ni-evidentemente-la desfasada partidocracia las que mejor pueden atenderlas. Es una auténtica democracia liberal porque, como nos lo recuerdan autores como Francis Fukuyama, la democracia es el único sistema que reconoce la dignidad y los derechos humanos de todos los integrantes de la comunidad política. ${ }^{7}$ Solo mediante la democratización de las estructuras constitucionales y electorales lograremos preservar y adecuar nuestro sistema político a nuestras necesidades. La manera más legítima, democrática y efectiva para lograr esta adecuación es una asamblea constituyente formada a partir de la más amplia participación ciudadana.

Un motivo adicional para promover la democracia es el anhelo histórico, abrigado por Panamá y todos los pueblos de buena voluntad, de contribuir a la paz mundial. Desde hace mucho tiempo se ha observado que los países democráticos constituyen entre sí una zona de paz. Los Estados democráticos resuelven las diferencias que surgen entre ellos por medios pacíficos, no a través de la guerra. No en vano, la Carta y otros documentos constitutivos de la OEA proponen para los países del nuestro hemisferio un esquema democrático como instrumento para lograr la satisfacción de las demandas populares y la paz entre los Estados del continente. Ciertamente, la Carta de la OEA indica que "la democracia representativa es condición indispensable para la estabilidad, la paz y el desarrollo de la región", por lo cual establece, como uno de sus principales propósitos, el de "promover y consolidar la democracia representativa dentro del respeto al principio de no intervención” (Art. 2b).

En Panamá, la propuesta de afianzary profundizar la democracia va de la mano de la desmilitarización de los servicios de seguridad. Años atrás uno de nuestros más brillantes estadistas, el Dr. Carlos Iván Zúñiga, planteó la creación de la zona desmilitarizada de América, inicialmente entre Panamá y Costa Rica-el país de más larga tradición democrática en Latinoamérica-sobre la base de los rasgos compartidos entre ambos Estados: la democracia y la proscripción del ejército. ${ }^{9}$ Para beneficio de nuestros pueblos, esta propuesta debe ser retomada e implementada, con el apoyo de la OEA, pues el militarismo y la negación de la democracia por los que propugnan algunos sectores solo conducen a mayor desdicha y tribulación.

Señor Secretario General, señoras y señores: Vivimos tiempos muy cruciales para la democracia. En Panamá, el sistema de gobierno instaurado en 1990 da muestras de agotamiento y la frustración popular aumenta, sin que existan las válvulas de escape para evitar un estallido, porque el sistema constitucional y electoral de la democracia panameña es inadecuado a nuestras necesidades. Hemos visto cómo en otras partes del hemisferio, la incapacidad de respuesta del sistema político ha sido el aliciente para una explosión social. Esta ha sidola reciente experiencia de Chile, un Estado que transitó a la democracia casi al mismo tiempo que nosotros y, al igual que Panamá, mantiene esquemas de gobierno heredados de la dictadura, inadecuados en tiempos democráticos.

\footnotetext{
${ }^{7}$ Francis Fukuyama, The End of History and the Last Man (New York: Avon Books, 1993).

${ }^{8}$ Organización de los Estados Americanos (OEA), "Carta de la Organización de los Estados Americanos", en http://www.oas.org/es/sla/ddi/docs/tratados multilaterales interamericanos A-41 carta OEA.pdf. Acceso: 17 de febrero de 2020.

${ }^{9}$ Carlos Iván Zúñiga, “Hacia la desmilitarización de América Latina”, La Prensa, 14 de mayo de 2005.
} 
En otras partes de la región, así como fuera de ella, la democracia pierde espacios frente al autoritarismo. En Estados Unidos, cuya arquitectura constitucional sirvió de modelo para el republicanismo democrático en todo el mundo, un discurso populista, agresivo y neo-nacionalista contribuye a desvalorizar la democracia y el Estado de derecho, según lo reconoce Freedom House en su más reciente informe. ${ }^{10}$ Brasil, India, Filipinas y otros países experimentan situaciones muy parecidas mientras que, en Europa, cuyo pensamiento ilustrado iluminó por años los esfuerzos por establecer sistemas de gobierno respetuosos de la ley y los derechos humanos, el ultranacionalismo y la intolerancia van en aumento, menoscabando logros alcanzados a lo largo de los siglos.

Rusia y China, grandes potencias que, en la actualidad, incrementan su posición internacional, son hostiles a la democracia. Y en una América Latina que, treinta años atrás, navegaba con entusiasmo sobre la tercera ola de la democracia, en años recientes las pérdidas democráticas se han acentuado considerablemente.

Hoy, solo ocho Estados (de un total de veinte en la región) son considerados "libres". ${ }^{11}$ Nueve son parcialmente libres y tres_el número más alto desde 1989—son dictaduras: Cuba, Nicaragua y Venezuela. ${ }^{12}$

Este retroceso democrático en países vecinos y otros continentes debe constituir un importante llamado de atención a los panameños, para sanear y recomponer nuestro sistema constitucional y electoral de forma tal que logremos un afianzamiento de la democracia, el gobierno republicano, el Estado de derecho y el ejercicio de las libertades fundamentales en nuestro istmo. Hacia ese fin, ojalá podamos contar con el apoyo de la OEA, hoy mucho más comprometida con la democracia que en etapas anteriores.

Nota del Editor:

El texto corresponde a la ponencia presentada por el Dr. Guevara Mann, dentro del simposio "Panamá ante los nuevos desafíos a la paz social y la democracia en América Latina”, impartido en la Cámara de Comercio, Industrias y Agricultura de Panamá, el martes 18 de febrero de 2020.

\footnotetext{
${ }^{10}$ Freedom House, Freedom in the World 2019: Democracy in Retreat (Washington:Freedom House, 2019), en https://freedomhouse.org/report/freedom-world/freedom-world-2019/democracy-in-retreat. Acceso: 16 de febrero de 2020.

${ }^{11}$ Argentina, Brasil, Chile, Costa Rica, El Salvador, Panamá, Perú y Uruguay

${ }^{12}$ Freedom House, "About Freedom in the World: Country and Territory Ratings and Statuses, 1973-2019 (Excel)," en https://freedomhouse.org/report-types/freedom-world. Acceso: 16 de febrero de 2020.
} 